\title{
STRATEGI PEMBELAJARAN AKTIF TIPE LEARNING STARS WITH A QUESTION (LSQ) DISERTAI HANDOUT PADA MATERI SISTEM GERAK KELAS VIII DI SMPN 22 PADANG
}

\section{Ruth Rize Paas Megahati S}

Program Studi Pendidikan BiologiSTKIP PGRI Sumatera Barat.

J1. Gunung Pangilun Padang, Kota Padang, Sumatera Barat, Indonesia. Telp./Fax. (0751) 7053731/ (0751) 7053826. Email : megahati71@gmail.com (Diterima 8 Mei 2015, disetujui 13 Juni 2015)

\begin{abstract}
The results of students in the systems subjectmotion system in class VIII SMPN 22 Padang is still under KKM. The reason is lack of appropriate learning strategies, student participation is low and lack of focus students' attention to the teacher's explanation in biology learning. This can be overcome by applying active learning strategies Learning type Stars With A Question (LSQ) accompanied handout. This study aims to improve student learning outcomes and type of research is experimental. The population in this study were all students of class VIII SMPN 22 Padang. Sampling using purposive sampling, in order to obtain two classes of samples and to draw the generated class VIII4 as an experimental class and class VIII3 as the control class. Data were analyzed using t-test and the results of the analysis of data obtained thitung > ttable, so the hypothesis is accepted. It can be concluded that the type of active learning strategies LSQ with handouts can improve learning outcomes biology class VIII SMPN 22 Padang.
\end{abstract}

Keywords:Active Lesson,Learning Stars With A Question, LSQ, handout

\begin{abstract}
ABSTRAK
Hasil belajar siswa pada materi sistem gerak kelas VIII SMPN 22 Padang masih di bawah KKM. Penyebabnya adalah strategi pembelajaran kurang tepat, partisipasi siswa rendah dan kurang fokusnya siswa memperhatikan penjelasan guru dalam pembelajaran Biologi. Hal ini dapat diatasi dengan menerapkan strategi pembelajaran aktif tipe Learning Stars With A Question (LSQ) disertai handout. Penelitian ini bertujuan untuk meningkatkan hasil belajar siswa dan jenis penelitian ini adalah penelitian eksperimen. Populasi dalam penelitian ini adalah seluruh siswa kelas VIII SMPN 22 Padang. Pengambilan sampel menggunakan teknik purposive sampling, sehingga diperoleh 2 kelas sampel dan dengan pengundian maka dihasilkan kelas $\mathrm{VIII}_{4}$ sebagai kelas eksperimen dan kelas $\mathrm{VIII}_{3}$ sebagai kelas kontrol. Teknik analisis data menggunakan uji-t dan hasil analisis data didapatkan $t_{\text {hitung }}>t_{t a b e l}$, dengan demikian hipotesis diterima. Dapat disimpulkan bahwa strategi pembelajaran aktif tipe LSQ disertai handout dapat meningkatkan hasil belajar Biologi siswa kelas VIII SMPN 22 Padang.
\end{abstract}


Kata kunci:Pembelajaran aktif, Learning Stars With A Question, LSQ, handout

\section{PENDAHULUAN}

Salah satu upaya untuk meningkatkan mutu pendidikan di sekolah adalah dengan cara perbaikan proses belajar mengajar atau pembelajaran. Berbagai konsep dan wawasan baru tentang pembelajaran di sekolah telah muncul dan berkembang seiring pesatnya ilmu pengetahuan dan teknologi.

Berdasarkan observasi dan wawancara serta data yang diperoleh dari guru Biologi di kelas VIII di SMP N 22 Padang diperoleh informasi bahwapartisipasi siswa dalam materi sistem gerak masih rendah, siswa kurang tertarik dengan strategi guru menyampaikan materi, sebagian siswa kurang termotivasi untuk belajar, dalam pengajaran siswa hanya bersikap menerima informasi yang diberikan guru, siswa tidak mempunyai buku pegangan sehingga pemahaman siswa mengenai materi yang dipelajari kurang berkembang. Hal ini disebabkan karena perpustakaan sekolah tidak mempunyai jumlah buku yang banyak, jumlah buku tidak sebanding dengan jumlah siswa. Dalam pembelajaran siswa malas bertanya dan sering kali guru mengira siswa sudah mengerti namun usaha tersebut belum dapat mencapai hasil yang diharapkan.

Rendahnya nilai rata-rata Ulangan Harian (UH) pada materi sistem gerak pada manusia siswa kelas VIII yang berada dibawah Kriteria Ketuntasan Minimum (KKM). Nilai KKM yang ditentukan sekolah SMP N 22 padang adalah 72.

Untuk mengatasi permasalahan dan meningkatkan hasil belajar, maka guru perlu menerapkan suatu strategi dalam pembelajaran Biologiagar siswa aktif dalam proses pembelajaran, seperti strategi pembelajaran aktif tipe Learning Stars With A Question (LSQ). Silberman (2007:144) mengemukakan bahwa strategi pembelajaran aktif tipe LSQ merupakan salah satu tipe belajar aktif yang meminta siswa untuk menyelidiki atau mempelajari sendiri materi pelajaran tanpa penjelasan terlebih dahulu dari guru. Siswa diberi kesempatan untuk mengajukan pertanyaan sebanyak mungkin mengenai hal-hal yang tidak dipahami dari materi tersebut. 
Sehubungan dengan adanya strategi pembelajaran tipeLSQmaka penulis perlu adanya suatu bahan ajar yang dapat digunakan dalam pembelajaran Biologi. Kehadiran bahan ajar dalam penerapan strategi pembelajaran tipeLSQmempunyai arti penting karena kerumitan materi serta pertanyaan yang akan disampaikan dan diajukan dapat disederhanakan dan mudah dipahami siswa dengan bantuan bahan ajar berupa handout. Menurut Majid (20011:175)Handout adalah bahan tertulis yang disiapkan oleh seorang guru untuk memperkaya pengetahuan pendidik.

Penerapan strategi pembelajaran aktif tipe Learning Stars With A Question disertai handoutdiharapkan dapat meningkatkan hasil belajar siswa serta dapat menimbulkan minat siswa dalam proses pembelajaranBiologi.

\section{METODE PENELITIAN}

Jenis penelitian ini adalah penelitian eksperimen dengan dua kelas yaitu kelas eksperimen dan kelas kontrol, maka rancangan penelitian ini Randomized Control Group Posstest Only Design (Lufri (2005:68)

Populasi dalam penelitian ini seluruh siswa kelas VIII SMP N 22 Padang yang tersebar dalam 8 kelas yang pengambilannya dengan teknik Porpusive Sampling dimana kelas eksperimen adalah $\mathrm{VIII}_{4}$ dan kelas kontrol adalah $\mathrm{VIII}_{3}$.

Jenis data yang digunakan adalah data primer dan sekunder. Teknik analisis data antara lain rumus validitas dan reliabilitas dikemukakanArikunto (2010), indeks kesukaran dan daya beda soal yang dikemukakanDepdiknas (2001), dan mencari uji normalitas, uji homogenitas dan uji hipotesis dikemukakan Sudjana (2005).

\section{HASIL DAN PEMBAHASAN}

Rata-rata hasil belajar siswa kelas eksperimen dengan penerapkan strategi pembelajaran aktif tipe Learning tipe LSQ disertai Handout $(79,08)$ lebih tinggi dari kelas kontrol $(61,46)$.

Penggunaan strategi LSQ mampu membuat siswa lebih berpartisipasi dalam kegiatan pembelajaran, karena dalam strategi pembelajaran LSQ siswa dituntut belajar aktif. Hal ini sesuai dengan yang diungkapkan Silberman (2007:144) bahwa LSQmerupakan salah satu tipe belajar aktif yang meminta 
siswa untuk menyelidiki atau mempelajari sendiri materi pelajaran tanpa penjelasan terlebih dahulu dari guru.

Selain itu peningkatan hasil belajar siswa melalui strategi pembelajaran tipe LSQ yaitu siswa diberi kesempatan untuk mengajukan pertanyaan sebanyak mungkin mengenai hal-hal yang tidak dipahami dari materi tersebut, dari pertanyaan siswa itulah guru menerangkan materi pembelajaran kepada siswa. Kegiatan bertanya adalah salah satu unsur penting dalam penerapan belajar aktif tipe LSQ. Hal ini sesuai dengan pendapat Silberman (2007:144) yang mengemukakan bahwa "Cara untuk menciptakan pola belajar aktif tipe LSQ adalah merangsang peserta didik untuk bertanya tentang mata pelajaran mereka, tanpa penjelasan terlebih dahulu. Bertanya merupakan kunci belajar”. Membuat siswa bertanya tentang suatu materi merupakan suatu strategi mengajar yang melibatkan siswa secara aktif dalam proses pembelajaran, sehingga dapat melatih kemampuan siswa.

Hasil belajar siswa pada kelas eksperimen juga didukung oleh adanya penggunaan bahan ajar, dimana bahan ajar yang digunakan adalah handout. Sebelum guru memulai pelajaran, guru membagikan handout terlebih dahulu kepada masing-masing siswa. Dengan adanya handout tersebut membuat siswa termotivasi untuk belajar, karena adanya gambar-gambar yang sangat jelas sehingga konsentrasi siswa lebih terfokus pada proses pembelajaran dalam penerapan strategi pembelajaran LSQ. Hal ini terlihat ketika guru menyuruh siswa membuat pertanyaan sebanyak mungkin mengenai materi yang tidak dipahaminya dan semua siswa mengerjakannya. Setelah selesai membuat pertanyaan guru menyuruh siswa berpasangan kedepan membacakan pertanyaan yang dibuatnya dan siswa lain diberi kesempatan menjawab pertanyaan tersebut, Pada saat guru menanyakan ada yang bisa menjawab banyak siswa yang menunjuk tangannya dengan begitu semangat, padahal biasanya siswa kurang aktif dan tidak semangat untuk belajar karena mereka tidak memiliki buku pegangan yang akan dibaca,sehingga dalam proses pembelajaran hasil belajar meningkatdengan persentase KKM kelas eksperimen 85\% dan kelas kontrol $12 \%$.

Menurut Majid (2011:175) "handout adalah bahan tertulis yang disiapkan oleh seorang guru untuk memperkaya pengetahuan peserta didik". Selain itu 
handout disusun atas dasar kompetensi dasar yang harus dicapai oleh peserta didik. Penggunaan bahan ajar dalam penelitian ini dapat memperlancar dan memberikan bantuan informasi atau materi pembelajaran sebagai pegangan bagi peserta didik.Keuntungan penggunaan media handoutadalah dapat menghemat waktu, menggantikan catatan siswa memelihara kekonsistenan penyampaian materi dikelas oleh guru siswa dapat mengikuti struktur pelajaran dengan baik dan siswa akan mengetahui pokok yang diberikan oleh guru.

Pada kelas kontrol nilai hasil belajar di bawah rata-rata kelas eksperimen. Hal ini disebabkan pada kelas kontrol diadakan diskusi yaitu diberikan lembaran LKS, lalu siswa disuruh mengisi LKS tersebut tetapi tidak semua siswa yang ikut bekerja, sebagian siswa tidak peduli sama sekali dengan tugas yang diberikan. Hal ini disebabkan karena siswa tidak mempunyai buku pegangan sebagai pedoman sehingga mereka tidak tahu apa yang akan dikerjakan, tetapi ada juga siswa yang memiliki buku sumber yang mereka pinjam dari pustaka, sehingga kelompok yang memiliki buku saja yang mengerjakan LKS yang diberikan, tetapi pada saat guru menempelkan charta siswa semangat mau menolongnya. Pada pembelajaran ini siswa cenderung pasif dan hanya menerima apa yang diberikan oleh guru. Hal ini terbukti pada saat guru memberikan kesempatan kepada siswa untuk bertanya tidak ada satupun siswa yang mengajukan pertanyaan dan ketika guru menyuruh kelompok maju ke depan tidak satupun kelompok yang mau maju, sehingga hasil belajar kurang bagus yaitu dibawah KKM.

Kendala yang dihadapi pada kelas ekperimen adalah pada saat pertemuan pertama yaitu ketika salah satu satu pasangan mempresentasikan hasil diskusinya di depan kelas, siswa yang lain meribut di belakang. Namun, guru bisa menenangkan dengan cara menegaskan bahwa setiap pasangan harus membacakan hasil diskusinya masing-masing, sedangkan pada kelas kontrol kendala yang dihadapi adalah siswa dikelas kontrol banyak diam dan tidak aktif dalam belajar dan pada saat mengerjakan latihan siswa kesulitan mengerjakannya.

Penelitian yang relevan juga dilakukan oleh Hasan (2012) yang mengunakan strategi pembelajaran actif tipe Learning Stars With A Questionterhadap Aktivitas dan hasil belajar Biologi siswa Kelas X SMAN 2 Pancung Soal Kabupaten Pesisir Selatan Tahun Pelajaran 2011/2012. Riddya 
menemukan bahwa hasil belajar siswa yangmenggunakanstrategi actif tipe LSQlebih meningkat dari pada hasil belajar yang mengunakan metode konvensional yaitu metode ceramah dengan hasil nilai rata-rata kelas eksperimen 78,42 dan kelas kontrol 63,56.

\section{KESIMPULAN}

Berdasarkan data dan hasil dan analisis yang telah dilakukan pada penelitian ini dapat disimpulkan bahwa terdapat pengaruh penerapan strategi pembelajaran aktif tipe LSQ disertai Handout dalam pembelajaran Biologi siswa kelas VIII SMPN 22 Padang.

\section{DAFTAR PUSTAKA}

Arikunto, Suharsimi. 2010. Dasar-Dasar Evaluasi Pendidikan. Bumi Aksara:Jakarta.

Depdiknas, 2001. Penyusun Butir Soal dan Instrumen Penelitian. Depdiknas: Jakarta.

Hasan, Riddya. 2012. Pengaruh Penerapan Strategi Pembelajaran Aktif Tipe Learning Stars With A Question terhadap Aktivitas dan Hasil Belajar BiologiSiswa Kelas X SMAN 2 Pancung Soal. Program Studi Pendidikan Biologi STKIP: Padang.

Lufri. 2007. Kiat Memahami Metodologi dan Melakukan Penelitian. UNP Press : Padang.

Majid. 2011. Perencanaan Pembelajaran.Remaja Rosdakarya: Bandung.

Silberman, Melvin. 2007. Active Learning 101 Strategi Pembelajaran Aktif. Nuansa: Bandung.

Sudjana. 2005. Metoda Statistika. Tarsito: Bandung. 